\title{
Twihinate-Lamlaga Cretaceous carbonatites and related REE, Nb and apatite deposits in the Reguibat Shield (Dakhla province, Morocco)
}

\author{
Cheikh Elwali MALAININE ${ }^{1,3}$, Muhammad \\ OUABID $^{1,4}$, Jean-Louis BODINIER ${ }^{1,2}$, Fleurice
} PARAT $^{2}$, Otmane RAJI ${ }^{1}$, Jean-Marie DAUTRIA ${ }^{2}$, Nasrrddine $\mathrm{YOUBI}^{3}$, Moulay Ahmed BOUMEHDI ${ }^{3}$, Carlos J. GARRIDO 4

${ }^{1}$ Geology \& Sustainable Mining, Mohammed VI Polyechnique University, 43150 Benguerir, Morocco, cheikh-elwali.malainine@um6p.ma

${ }^{2}$ Geoscience Montpellier, Univeristy of Montpellier, Cedex-5 34095 Montpellier, France

${ }^{3}$ Geosciences, Georessources and Geohazards laboratory, Cadi Ayyad University, 4000 Marrakech, Morocco ${ }^{4}$ Instituto Andaluz de Ciencias de la Tierra (IACT), CSICUGR, 18100 Armilla, Granada, Spain.

This work focuses on the Twihinate-Lamlaga Cretaceous carbonatite annular intrusions in the western Reguibat Shield of the West African Craton (Morocco) which are partially or completely covered by iron oxides and silica rocks. The carbonatite activity produced two distinct calciocarbonatite facies (white and grey). Light REE-rich calcite and apatite with notable amount of phlogopite are the main rock-forming minerals of the white facies. The grey carbonatite occurs intruded the white facies, and is composed mainly of REEpoor calcite, heavy REE-rich apatite, oxyhydroxides (geothite, hematite) with minor quartz. They are highly mineralized with monazite-(Ce), synchysite-(Ce) and pyrochlore as the main REE- and Nb-bearing minerals. However, the iron oxide ( $>80$ vol. $\%$ goethite and hematite) and silicic rocks (mostly quartz) contain the highest REE (up to $1.2 \%)$ and $\mathrm{Nb}(0.5 \%)$ concentrations, represented mainly by Th-poor monazite and pyrochlore. Moreover, the carbonatites are also associated with apatite-rich rocks (up to 29 wt. \% $\mathrm{P}_{2} \mathrm{O}_{5}$ ) with significant heavy REE and $\mathrm{Y}$ enrichment. The observed critical metal and phosphate concentrations are explained by the superimposition of magmatic/hydrothermal and near-surface alteration processes. 